\title{
The Influence of Incentives and Non-Incentives Tax on Profit Management
}

\author{
Mujennah'1, Safriansyah', Kevin Tanu' ${ }^{1}$ \\ ${ }^{1}$ STIEI Banjarmasin, Indonesia
}

\begin{abstract}
Disclosure of financial statement information for companies in Indonesia is very important, especially for stakeholders who do not have access to company information, especially in profit management, so that stakeholders are able to make the right decisions. Profit management is a managerial activity for management in influencing and interfering with financial statements. Public companies have benefited greatly because the effective tax rate of the company will become smaller so that the company is able to manage profits. Effective tax planning methods through tax incentives and non-tax incentives can help and provide convenience for companies in their profit management. Researchers want to find out how incentive taxes and non-incentive taxes affect profit management. The first results of the study showed that two variables of projected tax incentives with tax planning and deferred tax expense, as well as one variable non-incentive tax projected through leverage, had no effect on profit management. The second results of these studies showed that two other tax incentive variables were projected with the current tax expense and the number of shares paid, and the projection of one non-incentive variable of tax through variable capital intensity ratio had an effect on profit management. Researchers found difficulties when analyzing profit management since not all companies have positive test results against profit management values; there was a company with negative profit management values. The differences between this study to other researchers were the object and variable of research.
\end{abstract}

Keywords: Tax Incentives, Non-Tax Incentives, Profit management

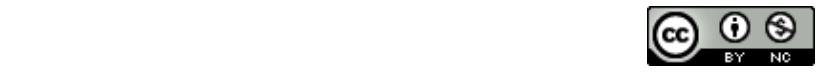

This is an open access article under the CC-BY-NC license

\section{INTRODUCTION}

Corporate profits were the most important information in the financial statements that often used as manipulation targets carried out by management to minimize and maximize profits. Profit management is a managerial activity for management in influencing and interfering with financial statements; the phenomenon of profit management practices in Indonesia often occurs because the management has confidence that stakeholders do not have access to company information, so stakeholders will consider the financial statements as true reports (Negara \& Suputra, 2017).

Financial statements are prone to be played first is the freedom to choose and use these accounting methods and procedures indirectly make accounting standards as if accommodating or facilitating this profit management actions. Taxes must be paid to the Government, but the company does not comply due to the opportunistic behaviour of the company. This caused the company's wealth to be improperly relocated, thus impacting the Government due to the incorrect amount of the tax received by the Government. High profits will cause the company's high tax expense so that it will motivate the company to do profit management. This also encourages the company to carry out tax management. This tax incentive is one of the first steps in tax management. Tax incentives in the form of reduced tax rates 
regulated The Minister of Finance Indonesia (Number 77, 2013) issued by the Government through the enactment of this tax rate; public companies will benefit greatly because the effective tax rate of the company will become smaller profits become more manageable.

The existence of market failures that occur from asymmetric information makes small-scale companies (MSMEs) difficult to develop and profit, so this is where tax incentives aim to reduce tax dystrophy to the investment climate for both small, medium, and large companies (OECD, 2013). The existence of tax incentive policies is more to prevent than encourage investment so that it has an impact on project costs and investment risks. Moreover, on the one hand, the country wants to get revenue from taxes, but on the other hand, the country also wants to create a large investment climate with low tax rates. Tax incentive schemes give the impression of an unstable tax system in a country because the low tax burden can encourage foreign investors to invest and improve the investment climate in the country (OECD, 2013).

Based on the background description and problem phenomenon above, the research wants to build the following problem formulation:

1. How did tax planning affect profit management?

2. How did the deferred tax expense affect profit management?

3. How did the current tax expense affect profit management?

4. How did the number of shares paid affect profit management?

5. How did leverage affect profit management?

6. How did the capital intensity ratio affect profit management?

7. How did profitability affect profit management?

\section{LITERATURE REVIEW}

\section{Positive Accounting Theory}

The theory of positive accounting explains and predicts accounting practices (Watts \& Zimmerman, 1990) consider that positive theory has provided clear confusion related to the choice of accounting techniques.

Tax Planning aims to minimize the burden of taxes owed, maximize the burden of taxes and meet tax obligations properly, efficiently, and effectively in accordance with the applicable tax provisions. The higher the tax planning, the greater the opportunity to do profit management; the practice of profit management is one of the accounting techniques allowed in positive accounting theory. Companies certainly want to reduce the burden of taxes to increase investment (OECD, 2013).

\section{Big Bath Theory}

Profit management of the big bath model is carried out with the aim of avoiding future burdens so that in the coming period, the company can earn greater profits. The profit management of the big bath model in the study was analyzed by looking at how low operating profit was, which was projected by return on asset (ROA) and return on sales (ROS) (Sevin \& Schroeder, 2005). Through the big bath, being able to adjust the report to the economic value of the company, through the way that removes assets when the carrying value of the company's assets is less than the market price this can reduce the information asymmetry, but also has an impact on investor confidence in investing on shares in the company (Kristian Hope \& Wang, 2018). 


\section{Profit management}

Profit management is managerial activity to "influence" and intervene in financial statements. Profit management is a deliberate step to regulate profit (Davidson, Stickney, \& Weil), interference in the composition of financial statements (Schipper), deliberate errors or omissions in making financial statements (National Association of Fraud Examiners), actions to regulate profit (Fisher \& Rosenzweig, 1995), flexibility that encourages profit abuse (Levitt, 1998) and use certain decisions to change financial statements (Healy \& Wahlen, 1999).

The empirical model for detecting management was first developed by Healy in 1985. In general, this model is no different from other models used to detect profit management in calculating the total value of accruals (TAC), i.e., reducing the accounting profit it earns over a certain period with the operating cash flow of the corresponding period. The accrual model involves the calculation of total accruals. Profit management is a selection of accounting policies conducted by managers to influence the company's profits, whose purpose is to achieve profits in profit reporting (Scott, 2015). Profit management measurements are done by calculating discretionary accrual using the modified Jones model (Jones, 1991) by (Dechow \& Sweeney, 1995).

The formula for finding total value of accruals (TAC), i.e., net income of year $t$ minus operating cash flow of year t with Modified Jones models (Dechow \& Sweeney, 1995) as follows:

$$
\text { 『TAC } \_ \text {it }=\llbracket \mathrm{NI} \rrbracket \_ \text {it }-\llbracket \mathrm{CFO} \rrbracket \_ \text {it }
$$

\section{Hypothesis Development}

Influence Of Incentive tax consisting of: Influence Of Tax Planning on Profit Management

According to (Agnes \& Yin, 2004) stated companies that have good tax planning will benefit in the form of tax shields and will minimize tax payments. Tax planning can also increase net profit, with effective tax planning will streamline the company's tax credit so as to increase the company's profit. Tax planning related to profit reporting, high profit will cause the corporate tax expense is also high, so it will motivate the company to do profit management which the researcher formulated with hypotheses 1: Tax planning (X1) effect on Profit Management (Y):

\section{Influence Of Deferred Tax Expense on Profit Management}

Taxation can be a motivation for managers to do profit management, namely by reducing taxable income using accounting methods in calculating inventory values, depreciation, and allowed reserves. The method of freedom provided by Financial Accounting Standards (IFRS) for companies to choose accounting methods in compiling financial statements had little difference with fiscal financial statements compiled by companies based on tax rules that do not give management the freedom to choose accounting models and accounting methods, this is what causes fiscal reconciliation.

Temporary differences between the amount of tax recorded assets or liabilities with the Basis of Taxation on such assets or liabilities. Timing differences occur due to differences in recognition of the amount of time in commercial accounting (IAS 12 on PSAK 46) compared to fiscally (Tax Regulation Number 36,2008$)$. The differences between commercial accounting profit and fiscal accounting will result in a correction in the form of a positive correction that will result in deferred tax assets, and a negative correction will result in deferred tax expense. Tax Regulation on Income Tax (Tax Regulation Number 36, 2008) "fiscal profit or taxable income is a profit calculated based on applicable taxation". 
Therefore the company can manage a small number of accounting profits through deferred tax expense (Arias \& Rodriguez, 2012). (Pincus, P.K, John D, Rego, \& 0, 2002) states: "The company's actions acknowledge early earnings and delay costs indicating that management conducts profit management on commercial, financial statements." the higher the profit management practices, the higher the deferred tax liabilities recognized by the company as a deferred tax expense", which the the researcher formulated with hypotheses 2 : Tax Planning (X2) effect on Profit Management (Y)

\section{Influence OfCurrent Tax Expense on Profit Management}

Current tax expense is the amount to be paid by the taxpayer based on taxable income multiplied by the tax rate, then paid by himself and reported in the Notification Letter (SPT) in accordance with the prevailing (Tax Regulation Number 36, 2008). The causes of the differences (fiscal correction) between income tax expense and taxes to be paid are categorized into two groups first, a) permanent differences $b$ ) temporary differences (Tax Regulation Number 36, 2008) Researcher formulated with hypotheses 3 : Current Tax (X3) effect on Profit Management (Y):

\section{Influence Of Number OfShares Paid on Profit Management}

Companies' regulation 33 chapter states that the shares put in IDX are paid in full by the owner. The number of shares paid had positive and significant across both measures of profit management, implied that the higher the number of shares paid, the more likely firms engage in all types of profit management (Doung \& Evans, 2016). The number of shares paid is assessed based on government regulation (Number 77,2013 ), if the shares paid by the company traded in the IDX $<40 \%$ then 0 and if the company's paid-up shares are $\geq 40 \%$, then 1 . The researcher formulated with hypotheses 4 : Number of Shares Paid (X4) effect on Profit Management (Y)

\section{Influence Of Non-Incentives Tax on Profit Management Consist Of:}

Influence Of Leverage on Profit Management

Highly leveraged companies are expected to make profit management increase reported profits and avoid breaches of debt covenants and the possibility to obtain additional funds from creditors. Leverage had a positive effect on earnings management (Lazzem \& Jilani, 2017), and the other studies found a negative relationship (Rodriguez \& Van Hemman, 2010). The researcher formulated hypotheses with Leverage (X5) affects on Profit Management (Y):

\section{Influence OfCapital Intensity Ratio On Profit Management}

Depreciation costs can be used by the company's management to reduce profits so that later it will be able to affect the amount of tax to be paid. The greater the number of fixed assets of the company, the lower the amount of tax paid annually than the company having a lower amount of fixed assets (Arias \& Rodriguez, 2012). The researcher formulated this with hypotheses 6: Leverage (X6) affects on Profit Management (Y):

\section{Influence Of Profitability On Profit Management}

(Kothari, A.J, \& Wasley, 2005) and (Ayu, 2019) was founded negative impact. The result showed that the higher or lower profitability obtained in companies had no effect on profit management. The researcher formulated this with hypotheses 7: Leverage (X7) affects on Profit Management (Y): 


\section{RESEARCH METHOD}

This research aims to develop previous research and can be classified into causal research types; researcher had to test independent variables between incentives tax consist of (tax planning, deferred tax expense, current tax expense, number of shares paid) and non-incentives tax consist of (leverage, capital intensity ratio and profitability) on company dependent variables (profit management) on LQ45 in the period 2017-2019.

Based on the research approach, the type of research was quantitative research with secondary data to prove the existing theory through multiple linear regression analysis, with the SPSS 25.0 as the test tool (Ghozali, 2016). The research population was obtained using purposive sampling techniques in LQ 45 companies listed in the period 2017-2019. Population targets was determined by criteria: (1) Companies listed on LQ 45 during period 2017-2019, (2) LQ45 companies that report full financial statements for the period 2017-2019, and (3) company that didn't have negative profit value for three consecutive years. Multiple linear regression equations used by researchers as follows:

$$
\mathrm{TAC}=\alpha+\beta_{1} T_{R R_{i t}}+\beta_{2} \mathrm{DTE}_{i t}+\beta_{3} C T E_{i t}+\beta_{4} S T O C K_{i t}+\beta_{5} L E V_{i t}+\beta_{6} C I R_{i t}+\beta_{87} R O A_{i t}+\varepsilon_{i t(1)}
$$

\section{FINDINGS AND DISCUSSION}

\section{Point 1 Regression test result}

Recapitulation of Multiple Regression Test Results is showed in the following table:

\begin{tabular}{|l|r|r|r|r|}
\hline \multicolumn{1}{|c|}{ Variable } & $\begin{array}{r}\text { Coefficient } \\
\text { Regression }\end{array}$ & $\begin{array}{c}\text { Coefficient } \\
\text { Beta }\end{array}$ & t count & Prob (Sig.) \\
\hline Tax Planning $\left(\mathrm{X}_{1}\right)$ & -0.226 & 0.271 & -0.835 & 0.413 \\
\hline Deferred Tax Expense (X2) & 0.716 & 0.121 & 1.451 & 0.161 \\
\hline Current Tax Expense (X3) & -0.431 & 0.202 & -2.134 & 0.044 \\
\hline Number of Share paid (X4) & 7,170 & 1,465 & 4,895 & 0,000 \\
\hline Leverage (X5) & 0,928 & 0,177 & 5,227 & 0,000 \\
\hline Profitability (X6) & 0,592 & 1,297 & 0,456 & 0,653 \\
\hline Capital Intensity Ratio (X7) & 10,833 & 2,720 & 3,983 & 0,001 \\
\hline Cons & $\mathbf{0 . 0 2 3}$ & & & \\
F count & $\mathbf{6 7 4 . 1 1}$ & & & \\
R & $\mathbf{0 . 9 9 8}$ & & & \\
$\mathbf{R}^{2}$ & $\mathbf{0 . 9 9 5}$ & & & \\
Adjusted R & $\mathbf{0 , 9 9 4}$ & $\mathbf{0}$ & & \\
Sig. F & $\mathbf{6 . 3 2 4}$ & & \\
SEE & & & & \\
\hline
\end{tabular}

Table 1. the result of multiple regression analysis with SPSS 25.0 (processed data, 2021)

The results of multiple regression tests as follows:

\section{$\mathrm{TAC}=0.023+(-0.226) \mathrm{TRR}+0.716 \mathrm{DTE}+(-0.431) \mathrm{CTE}+7.170 \mathrm{Stock}+0.928 \mathrm{DER}+0.59 \mathrm{ROA}$ $+10.833 \mathrm{CIR}$}

This study used profit management as a dependent variable and tax planning, deferred tax expense, current tax expense, number of shares paid, leverage, profitability, and capital intensity ratio as an independent variables.

The other variable from deferred tax expense, number of shares paid, leverage, profitability, capital intensity ratio had coefficient positive, and this value explains that there is a positive influence between 
variable deferred tax expense, number of shares paid, leverage, capital intensity ratio, and profitability to profit management.

This research model shows that tax planning, deferred tax expense, current tax expense, leverage, number of shares paid, profitability, capital intensity ratio simultaneously have significant effects on the dependent variable of profit management.

\section{Point $2 \mathrm{~F}$ test result}

If the test significance value $\mathrm{F}<0.05$, then the model used in the study is feasible and can be used for subsequent analysis, and vice versa (Ghozali, 2016). The table 1 result test showed that F-statistics probability is below $1 \%$, which 0,000 , so the researcher concluded that variables of tax planning, deferred tax expense, current tax expense, number of shares paid, leverage, capital intensity ratio, and profitability together had a significant effect on the profit management at the level of $1 \%$.

\section{Point 3 t-test result}

\section{Impact Of Tax Planning on Profit management}

The results of this study are different from (Agnes \& Yin, 2004) study, which states that tax planning can also increase net profit, with effective tax planning will streamline the company's tax credit so as to increase the company's profit. Statistically evidenced found by the value of t-count (1.755) < t-table 2.042 and significance value of $0.413>0.05$, thus indicating that tax planning had no influence and was insignificant. The resulting test showed that there had no effect on profit management, so $\mathrm{H} 1$ was rejected. Researchers concluded that good tax planning will be inversely proportional to profit management; these results were in line with the results of research conducted by (Ayu, 2019).

\section{Impact Of Deferred Tax Expense on Profit management}

The company managed a small number of accounting profits through deferred tax expenses (Arias \& Rodriguez, 2012). (Pincus, P.K, John D, Rego, \& 0, 2002) states: "The company's actions acknowledge early earnings and delay costs indicating that management conducts profit management on commercial, financial statements." the higher the profit management practices, the higher the deferred tax liabilities recognized by the company as a deferred tax expense." The test results stated that the Deferred Tax Expense had no effect on profit management, so $\mathrm{H} 2$ was rejected. This is statistically evidenced by the value of tcount (1.451) <ttable 1.7139 and the significance value of $0.161>0.05$. Deferred tax expenses had a negative influence on profit management. Higher deferred tax expense so that likelihood of the company doing profit management will decrease, and vice versa. This is inversely proportional to research (Negara \& Suputra, 2017) that stated the positive and significant relationship between deferred tax expense and profit management.

\section{Impact Of Current Tax Expense on Profit management}

Test results showed the current tax expense had an influence on profit management with the comparison of tccount with ttable, obtained the value of tcount -2.134 statistically $>$ ttable 1.7139 and the significance value of $0.04<0.05$ so that $\mathrm{H} 3$ was accepted. The result means that the current tax expense had a significant effect on profit management; it was concluded that the higher the tax burden now, it can improve profit management even though the effect is negative (weak), and this result is in line with government tax regulations (Tax Regulation Number 36, 2008). 


\section{Impact Of Number OfShares Paid On Profit management}

A number of shares paid shows a significant value of $0.000<0.05$ with a comparison of taccount and ttable, obtained the value of tccount (4.895) statistically> ttable 1.7139 and significance value of 0.00 $<0.05$. The authors found out that a number of shares paid have a positive and significant influence on profit management, so that H4 was accepted. The results test line with (Doung \& Evans, 2016), which states the results that the higher the number of shares paid, the more likely firms engage in all types of profit management.

\section{Impact Of Leverage on Profit management}

Higher corporate leverage can trigger improved profit management. Leverage got significant value of $0.000<0.05$. It can be concluded leverage has a significant effect on profit management so that $\mathrm{H} 4$ was accepted. Highly leveraged companies are expected to make profit management increase reported profits. These results wasn't in line with previous research conducted by (Lazzem \& Jilani, 2017) but in line with research conducted by (Rodriguez \& Van Hemman, 2010).

\section{Impact Of Capital Intensity Ratio on Profit management}

Capital intensity ratio obtained t count of 3,983 and table $t 1.7139$. The researcher found out that the Capital intensity ratio has an effect on profit management so that $\mathrm{H} 6$ is accepted. The results of this study conducted by (Rodriguez \& Van Hemman, 2010) stated that the greater the capital intensity ratio so the more likely the company to carry out profit management is higher.

\section{Impact Of Profitability on Profit management}

Profitability has no effect on profit management because management in developing businesses prioritizes its own capital over loans. From the results of the comparison of tcount with ttable, obtained the value of tcount $0.456<$ ttable 1.7139 and the significance value of $0.653>0.05$ statistically. The researcher found that profitability has no effect on profit management, so $\mathrm{H} 5$ is rejected. This means that the more profit levels, the probability of the company carrying out profit management are slight (small). Researchers have similar results with previous researchers, namely (Kothari, A.J, \& Wasley, 2005) and (Ayu, 2019). They were founded that the higher or lower profitability obtained in companies had no effect on profit management.

\section{CONCLUSION}

Partially based on the result, the researcher found out that the projected tax incentives with tax planning and deferred tax expense had no significant impact on profit management. The current tax expense and number of shares paid have significant effects on profit management. Partially based on results, the researcher found out that the projected non-tax incentives with leverage and capital intensity ratio have a significant impact on profit management. Profitability had no significant effect on profit management.

The results of the analysis showed the current tax expense, the number of shares paid, leverage, profitability, and capital intensity ratio affect profit management. Meanwhile, tax planning, deferred tax expense, and leverage had no significant effect on profit management.

\section{LIMITATION \& FURTHER RESEARCH}


Researchers found difficulties when analyzing profit management because not all companies had positive profit management values; there are some companies with negative profit management values. The differences between this study are the object and variable of research. The limitation of the study that can be concluded is that this study only uses a short span of time that is for three years. Researchers found difficulties when analyzing profit management because not all companies had positive profit management values; there are some companies with negative profit management values. Further research is expected to be able to develop new variable variables that are more updated so that researchers can further develop a relationship between tax incentives, tax policy, governance, and non-taxes with the audit field.

\section{REFERENCES}

Agnes, C., \& Yin, J. (2004). Earning Management Of Profit Firms and Loss Firms in Response to Tax Rate Reduction. Review of Accounting and Finance, 3, 67-92.

Arias, A., \& Rodriguez, E. (2012). Do Business Characteristics Determine an Effective Tax Rate? The Chinese Economy, 45:6. doi:10.2753/CES1097-1475450604

Ayu, B. (2019, October). Pengaruh Insentif Pajak dan Insentif Non Pajak Terhadap Manajemen Laba. Retrieved from dspace.uii.adc.id: https://dspace.uii.ac.id/handle/123456789/17167

Davidson, S., Stickney, C., \& Weil, R. (n.d.). Intermediate accounting: Concepts, methods and use. Forthworth. 4. Dryden Press.

Dechow, P., \& Sweeney, A. (1995). Detecting earning management. Account. Rev, 70(2), 193-225. Retrieved from : http://www.jstor.org/stable/248303

Doung, L., \& Evans, J. (2016). , Gender differences in compensation. Australia: Pacific-Basin Finance Journal. DOI: DOI: 10.1016/j.pacfin.2016.07.00

Fisher, M., \& Rosenzweig, K. (1995). Attitudes of students and accounting practitioners concerning the ethical acceptability of earnings management, 14, pp. 433-444. Dayton, USA. doi:https://doi.org/10.1007/BF00872085

Ghozali, I. (2016). Aplikasi Analisis Multivariate Dengan Program IBM SPSS 23 (Vol. VIII). (8, Ed.) Semarang: Badan Penerbit Universitas Diponegoro.

Healy, P., \& Wahlen, J. (1999, November). A Review of the Earnings Management Literature and its Implications for Standard Setting. doi:http://dx.doi.org/10.2139/ssrn.156445

Jones, J. (1991). “Earnings Management During Import Relief Investigations. Journal of Accounting Research, 29, 193-228.

Kothari, S., A.J, \& Wasley, C. (2005). Performance method discretionary accruals measures. Journal of Accounting and Economics, 39(1), 163-197.

Kristian Hope, O., \& Wang, J. (2018). Management deception, big bath accounting, and information asymmetry. Evidence from Linguistic analysis. Accounting, Organizations and Society, 70, 33-51. doi:https://doi.org/10.1016/j.aos.2018.02.004.

Lazzem, S., \& Jilani, F. (2017). The impact of leverage on accrual-based earnings management. Research in International Business and Finance, 17(S0275-5319 300074-0). doi:http://dx.doi.org/10.1016/j.ribaf.2017.07.103

Levitt, A. (1998). The number game. The CPA Journal, 68(12), 14-19.

Negara, A., \& Suputra, I. (2017, Agustus 31). Pengaruh Perencanaan Pajak dan Beban Pajak Tangguhan Terhadap Manajemen Laba. E-Jurnal Akuntansi, 20(3), 2045-2072. Retrieved 10 7, 2021, from https://ojs.unud.ac.id/index.php/Akuntansi/article/view/28499 
Number 77, G. (2013). Penurunan Tarif Pajak Penghasilan Bagi Wajib Pajak Badan Dalam Negeri yang Berbentuk Perseroan Terbuka. Retrieved from https://peraturan.bpk.go.id/Home/Details/5412

OECD. (2013). Policy Framework For Investment User's Toolkit. Retrieved from A Publication of The Investment Division of The OECD Directorate For Financial and Enterprise Affairs.: https://www.oecd.org/investment/toolkit/policyareas/41890309.pdf

Pincus, P.K, M., John D, P., Rego, \& O, S. (2002, October 14). Earnings Management Evidence-Based On Deferred Tax Expense. SSRN, 319, 52242-1000. doi:http://dx.doi.org/10.2139/ssrn.276997

Rodriguez, P., \& Van Hemman, S. (2010). Debt, Diversification and earnings management. Journal Of Accounting and Public Policy, 29(2), 138-159.

Scott, W. (2015). Financial Accounting Theory (Vol. 7). Canada: Prentice-Hall.

Sevin, S., \& Schroeder, R. (2005, Jan 1). Earnings Management;Evidence from SFAS No. 142 reporting. Managerial Auditing Journal, 20(1).

Tax Regulation Number 36. (2008, Sept 23). Retrieved from pajak.go.id: https://www.pajak.go.id/id/undang-undang-nomor-36-tahun-2008

Watts, R., \& Zimmerman, J. (1990). Positive Accounting Theory. The Accounting Review: : a ten year perspective, 65(1), 131-56. 